\title{
Profil Mikrobiologis dan Deteksi Mastitis dengan California Mastitis Test di Peternakan Sapi Perah Novisiat Claretian Benlutu
}

Yosef K. Tamur

${ }^{a}$ Fakultas Pertanian, Universitas Timor, Kefamenanu, TTU - NTT, 85613, Indonesia, email: tamurtanto@gmail.com

\section{Article Info}

\section{Article history:}

Received 18 Juni 2019

Received in revised form 03 Januari 2020 Accepted 30 Juli 2020

DOI:

https://doi.org/10.32938/ja.v5i4.757

Keywords:

Mastitis

Uji CMT

Sapi perah

Total bakteri susu

\section{Abstrak}

Penelitian ini dilaksanakan di Peternakan sapi perah Claretian Benlutu, Kecamatan Batu Putih, Kabupaten TTS dan laboratorium Penelitian ini terdiri dari 2 periode yaitu pengujian CMT dan dilanjutkan dengan analisis laboratorium. Tujuan penelitian ini adalah untuk mengetahui profil mikrobiologis dari susu yang terdeteksi penyakit mastitis dengan uji California Mastitis Test (CMT). Dalam penelitian ini digunakan 4 ekor ternak sapi perah yang sementara masa laktasi. Rancangan percobaan yang digunakan adalah uji deskriptif. Hasil penelitian berdasarka uji CMT dapat disimpulkan sapi perah yang dipelihara di biara Novisiat Claretian Benlutu mempunyai status mastitis subklinis, sehingga perlu pencegahan mastitis dalam tata laksana pemeliharaannya. Susu yang dihasilkan dari peternakan tersebut dalam keadaan yang baik, dilihat dari jumlah bakteri dan lama waktu reduktase yang sudah sesuai dengan standar SNI.

\section{Pendahuluan}

Susu merupakan salah satu sumber energi yang dibutuhkan tubuh serta merupakan bahan makanan yang bergizi tinggi, mengandung zat-zat makanan yang lengkap dan seimbang seperti protein, lemak, karbohidrat, mineral, dan vitamin yang sangat dibutuhkan oleh manusia. Kandungan gizi yang lengkap menjadi alasan tingginya kebutuhan dan permintaan masyarakat akan susu. Tingginya kebutuhan dan permintaan susu di Indonesia masih berbanding terbalik dengan rendahnya pemenuhan susu baik secara kuantitas maupun kualitas. Tingkat pemenuhan susu secara kuantitas masih sangat rendah.

Kualitas susu dari peternak sapi perah lokal secara umum juga masih di bawah standar dimana hal tersebut berdampak pada rendahnya harga jual ditingkat koperasi maupun industri pengolahan susu. Kendala susu sebagai salah satu produk peternakan yang mempunyai nilai gizi tinggi adalah mudah rusak. Penyebab kerusakan susu diantaranya adalah kontaminasi mikroba. Mikroba susu dapat berasal dari luar ambing yang masuk melalui puting pasca pemerahan atau saat proses pemerahan. Susu merupakan komoditas yang mudah rusak, mempunyai resiko tinggi, oleh karena itu perlu penanganan dan pengolahan yang hati-hati (Usmiati dan Abubakar, 2009).

Winarno (2004), mengatakan kerusakan pada susu dapat disebabkan oleh beberapa faktor yaitu, 1) Pertumbuhan dan aktivitas mikroba terutama bakteri, ragi dan kapang, 2) Aktivitas enzim-enzim di dalam susu. Enzim yang terdapat pada susu tersebut dapat berasal dari mikroba atau sudah ada pada bahan pangan tersebut secara normal. Adanya enzim memungkinkan terjadinya reaksi-reaksi kimia lebih cepat tergantung dari jenis enzim yang ada, selain itu juga dapat mengakibatkan bermacam-macam perubahan pada komposisi susu. 3) Kadar air sangat berpengaruh pada daya simpan susu karena air inilah yang membantu pertumbuhan mikroba.

Salah satu penyebab rendahnya produksi dan kualitas susu sapi perah dari aspek kesehatan adalah adanya penyakit mastitis. Mastitis merupakan peradangan pada jaringan internal ambing (Sudarwanto, 2009), mastitis bisa disebabkan oleh kuman patogen (infeksius) seperti bakteri, kapang atau khamir, kerusakan fisik ambing (udder and teat injury) serta akibat terpapar oleh bahan kimia yang iritan yang mampu merusak jaringan internal ambing (Anri, 2008). Menurut Jayarao dan Wolfgang (2003), mayor patogen penyebab mastitis terdiri atas tiga jenis kuman patogen yaitu Staphylococcus aureus, Streptococcus agalactiae dan Mycoplasma bovis. Infeksi bakteri merupakan penyebab utama terjadinya mastitis, bakteri penyebabnya adalah Staphylococcus aureus, Streptococcus agalactiae, Mycoplasma bovis, Streptococcus dysagalactiae, Streptococcus uberis dan berbagai jenis bakteri gram negatif, meskipun demikian lebih dari 130 jenis bakteri telah dilaporkan dapat menyebabkan penyakit atau kelainan pada kelenjar ambing sapi perah (Kirk dan Lauerman, 1994).

Bakteri-bakteri tersebut akan menyebabkan kerusakan-kerusakan sel-se alveoli pada ambing. Kerusakan yang terjadi tidak hanya mengakibatkan penurunan produksi susu namun juga kualitas susu. Penurunan kualitas susu merupakan kelainan pada susu karena bakteri mastitis merusak komposisi nutrien susu (Utami et al., 2014 dan Amran, 2013). Berdasarkan gejala klinisnya, penyakit mastitis dapat diklasifikasikan ke dalam mastitis klinis dan subklinis. Mastitis klinis dapat dideteksi melalui kelainan kualitas fisik susu seperti bercampur dengan darah, mengental dan terlihat pecah. Mastitis klinis juga menampakkan gejala kebengkakan ambing, terasa panas jika disentuh, warnanya memerah, peningkatan suhu tubuh, penurunan nafsu makan dan ternak akan merasa kesakitan jika diperah. Mastitis subklinis memiliki ciri-ciri berbeda dengan mastitis klinis karena pada kasus ini tidak menampilkan kelainan fisik susu maupun ambing. Mastitis subklinis hanya dapat dideteksi dengan cara tes tertentu seperti uji Californian Matitis Test (CMT), uji kimia susu dan kultur bakteri (Sudhan dan Sharma, 2010; Suwito dan Indarjulianto, 2013). Kejadian kasus mastitis sampai akhir tahun 2006 adalah sekitar $75-83 \%$ dengan prevalensi mastitis di Boyolali sebesar $62,5 \%$ (Sudarwanto dan Sudarnika, 2008).

Mastitis subklinis merupakan penyakit yang sangat merugikan secara ekonomi pada industri peternakan sapi perah yang telah lama diketahui dan telah dilaporkan dibanyak penelitian di dunia. Kerugian ekonomi yang ditimbulkan diantaranya penurunan kualitas susu, pengafkiran susu yang bermasalah dan biaya pengobatan. Prevalensi mastitis subklinis di peternakan rakyat sering sekali meresahkan produsen industri susu, terlebih lagi infeksi subklinis pada kuartir susu dapat berkembang menjadi mastitis klinis sehingga meningkatkan kejadian infeksi baru di peternakan (Ayano et al., 2013). Tujuan penelitian ini adalah untuk mengetahui profil mikrobiologis dari susu yang terdeteksi penyakit mastitis di peternakan sapi perah Novisiat Claretian Benlutu.

\section{Metode}

\subsection{Waktu dan Tempat Penelitian}

Penelitian ini dilaksanakan selama satu bulan di peternakan sapi perah Novisiat Claretian Benlutu Keuskupan Agung Kupang, Desa Benlutu Kecamatan Batu Putih Kabupaten Timor Tengah Selatan dan di laboratorium kimia UNIKA Kupang.

2.2 Alat dan Bahan

Peralatan yang digunakan adalah cawan petri, tabung reaksi, pipe volume $10 \mathrm{ml}$, oven, autoclave, erlenmeyer, rak tabung reaksi dan tisue. Sedangkan bahannya adalah susu sapi segar $2 \mathrm{ml}$, media agar $7 \mathrm{~g}$, aquades 250 $\mathrm{ml}$ dan alkohol.

\subsection{Metode Penelitian}

Penelitian ini menggunakan metode eksperimen dimana sampel susu yang diambil berasal dari puting yang telah terkena penyakit mastitis, diuj mikrobiologis metode angka lempeng total atau Standart Plate Count (SPC), uji Methylene Blue Reduction Test (MBRT) dan uji California mastitis test $(C M T)$.

\subsection{Prosedur Penelitian}

\subsubsection{Total Bakteri Standart Plate Count (SPC)}

Susu segar diambil sebanyak $0,1 \mathrm{ml}$ kemudian dicampur dengan Nutrien Agar (NA). Campuran tersebut dituang sampai ke seluruh permukaan petri tertutupi $(10-15 \mathrm{ml})$. Natrium Agar diratakan dan dibiarkan sampai beku. Cawan petri diinkubasi selama $2 \times 24$ jam di dalam inkubator dan dihitung jumlah koloni yang tumbuh.

\subsubsection{Methylene Blue Reduction Test (MBRT)}

Menurut Soetarno (2003) prosedur pengujian MBRT adalah sebagai berikut :

1. Sebanyak $1 \mathrm{ml}$ methylen blue dimasukan ke dalam tabung reaksi yang bertutup rapat

2. Susu sapi murni sebanyak $10 \mathrm{ml}$ dimasukkan kedalam tabung reaksi yang berisi metylene blue, campuran tersebut diinkubasi pada suhu $36^{\circ} \mathrm{C}$

3. Tabung reaksi dibaliksecara perlahan sebanyak 3 kali tanpa dikocok

4. Amati perubahan warnanya setiap $1 / 2$ jam dan catat waktu reduksi, yaitu $4 / 5$ bagian contoh susu di dalam tabung reaksi berubah warna menjadi putih.

\subsubsection{California Mastitis Test (CMT)}

Penelitian ini menggunakan empat ekor sapi Peranakan Friesien Holstein (PFH) yang terkena mastitis subklinis. Diagnosa mastitis subklinis menggunakan California mastitis test (CMT). Penelitian dilakukan $\mathrm{d}$ peternakan Novisiat Claretian Benlutu Timor Tengah Selatan. Diagnosa mastitis dilakukan dengan mengambil $2 \mathrm{ml}$ susu segar dari setiap puting sapi 
sebagai sampel. Susu tersebut diletakkan di paddle CMTdengan posisi vertikal. Larutan CMT ditambahkan ke masing- masing bagian paddle kemudian paddle $C M T$ diputar, sehingga susu dan larutan $C M T$ tercampur. Proses pencampuran tidak lebih dari 10 detik. Hasil yang terlihat dalam paddle CMT dibaca dengan cepat karena reaksi yang terlihat akan rusak dalam 20 detik. Penilaian reaksi ini secara visual lebih banyak gel yang terbentuk dan semakin besar nilainya. Pengamatan hasil pengujian CMT dapat dilihat pada Tabel 1.

\section{Tabel 1. Hasil pengujian $C M T$}

\section{Tanda}

Tidak terdapat gumpalan dan sangat encer

$\mathrm{T}$ Adanya gumpalan dan akan menghilang jika paddle diputar lagi

$+\quad$ Larutan mengental akan tetapi tidak condong menjadi gel dan akan menghilang jika paddle diputar lebih dari 20 detik

++ Terjadi gumpalan dan membentuk gel yang ringan, campuran akan menggumpal di tengah paddle dan akan melapisi bagian bawah apabila dibuang.

++ Terbentuknya gel yang sangat kuat dan sulit untuk digerakkan. (Sumber : Mellenberger dan Roth, 2000)

\subsection{Analisis Data} deskriptif.

Data yang diperoleh dalam penelitian ini dianalis menggunakan analisis

\section{Hasil dan Pembahasan}

\subsection{Deteksi Mastitis Sub Klinis (Uji CMT)}

Uji $C M T$ adalah salah satu uji tercepat dan termurah untuk mengetahui penyakit mastitis pada ternak perah. Uji CMT hendaknya dilakukan secara rutin untuk terus memantau status keparahan mastitis dalam suatu kawanan ternak. Hasil uji CMT yang dilakukan di Peternakan Novisiat Claretian Benlutu dapat dilihat di Tabel 2 .

Tabel 2. Hasil Uji CMT Sapi Perah Sebelum Perlakuan Celup Puting

\begin{tabular}{|c|c|c|c|c|c|c|c|c|c|c|c|c|}
\hline N0 & Pengl & kura & n 1 & & Pens & ukura & & & Pen & ukuir & n 3 & \\
\hline & $\mathrm{KD}$ & $\mathrm{KB}$ & KiD & $\mathrm{KiB}$ & KD & $\mathrm{KB}$ & KiD & $\mathrm{KiB}$ & $\mathrm{KD}$ & KB & KiD & $\mathrm{KiB}$ \\
\hline 1 & + & + & + & ++ & + & + & + & ++ & + & + & + & ++ \\
\hline 2 & + & + & + & + & + & + & + & + & + & + & + & + \\
\hline 3 & - & + & - & - & - & + & - & - & - & + & - & - \\
\hline 4 & $\mathrm{~T}$ & $\mathrm{~T}$ & $\mathrm{~T}$ & $\mathrm{~T}$ & $\mathrm{~T}$ & $\mathrm{~T}$ & $\mathrm{~T}$ & $\mathrm{~T}$ & $\mathrm{~T}$ & $\mathrm{~T}$ & $\mathrm{~T}$ & $\mathrm{~T}$ \\
\hline
\end{tabular}

Berdasarkan data Tabel 2, sapi-sapi di Peternakan Sapi Perah Novisiat Claretian Benlutu sebagian besar dalam keadaan menderita mastitis subklinis. Mastitis subklinis adalah mastitis yang tidak menampakkan perubahan fisik pada ambing dan susu yang dihasilkan, tetapi menyebabkan penurunan produksi susu, ditemukannya mikroorganisme patogen dan terjadi perubahan komposisi susu. Kasus mastitis subklinis pada sapi perah di Indonesia sangat tinggi sampai akhir 2006 mencapai 75-83\% menyebabkan kerugian yang besar (Sudarwanto et al., 2006). Menurut Anderson et al. (2010), mastitis subklinis lebih umum terjadi dari pada mastitis klinis. Kerugian terjadi akibat adanya kerusakan pada sel-sel epitel penghasil air susu dan jaringan ikat diantara selsel tersebut yang menyebabkan kapasitas produksi terus menurun secara permanen.

Jika mastitis subklinis dibiarkan maka status mastitis akan berubah menjadi klinis. Sapi-sapi yang ada di Novisiat Claretian Benlutu terlihat sehat dan tidak sakit. Setelah diuji mastitis ternyata sapi-sapi tersebut menderita mastitis sub klinis. Di Benlutu belum pernah dilakukan pencegahan untuk mengurangi gejala mastitis. Salah satu cara untuk pencegahannya adalah melakukan celup puting.

Pencelupan puting adalah salah satu cara yang digunakan peternak untuk meminimalisir terjadinya mastitis. Celup puting pasca pemerahan telah banyak dilakukan dan secara luas telah diterima sebagai salah satu perlakuan untuk mengurangi infeksi kelenjar susu (Galton, 2004). Rahayu (2009) melaporkan prevalensi mastitis subklinis pada umumnya mencapai $80 \%$ dan menyebabkan penurunan produksi susu sampai $15 \%$. Poeloengan (2009) menyatakan bahwa tingkat pertahanan ambing mencapai titik terendah saat sesudah pemerahan, karena sphincter masih terbuka beberapa saat, sel darah putih, antibodi, serta enzim juga habis ikut diperah. Menurut Siregar (2010) pencegahan terhadap mastitis dapat dilakukan dengan celup puting (teat dipping) setelah pemerahan dengan menggunakan antiseptik seperti povidone iodine dan chlorhexidin setelah pemerahan. Kegiatan celup puting setelah pemerahan dengan menggunakan antiseptik dilakukan untuk melindungi lubang puting sehingga mikroorganisme patogen tidak dapat masuk ke dalam puting dan menghindari terjadinya kerusakan susu (Sasongko et al. 2012). Celup puting setelah pemerahan telah banyak dilakukan dan secara luas sudah diterima sebagai salah satu perlakuan untuk mengurangi mastitis (Galton, 2004).

\subsection{Standar Plate Count (SPC)}

Susu merupakan produk hasil ternak perah yang bernilai gizi tinggi. Kandungan gizi yang tinggi pada susu memberi peluang bagi perkembangan bakteri, baik yang patogen maupun non patogen yang dapat menurunkan kualitas susu. Jumlah bakteri pada susu menentukan kualitas susu. Untuk mengetahui jumlah bakteri pada susu dapat dilakukan dengan uji mikrobiologis salah satunya dengan uji $S P C$. Uji $S P C$ merupakan cara untuk mengetahui jumlah bakteri dalam susu. Hasil uji $S P C$ pada susu sapi yang diperoleh dari peternakan Novisiat Claretian Benlutu dapat dilihat pada Tabel 3.

Tabel 3. Hasil uji Standar Plate Count (SPC) Sapi Perah.

\begin{tabular}{|c|c|c|c|c|c|c|}
\hline \multirow[t]{2}{*}{ No } & \multirow[t]{2}{*}{ Puting susu } & \multicolumn{3}{|c|}{ Perlakuan } & \multirow[t]{2}{*}{ Jumiah } & \multirow[t]{2}{*}{ Rata-rata } \\
\hline & & I & II & III & & \\
\hline & Kanan depan & 186 & 288 & 207 & 681 & 227,00 \\
\hline \multirow[t]{5}{*}{1} & Kanan belakang & 106 & 99 & 102 & 307 & 102,33 \\
\hline & Kiri depan & 156 & 102 & 180 & 438 & 146,00 \\
\hline & Kiri belakang & 77 & 67 & 72 & 216 & 72,00 \\
\hline & Total & & & & & 136,83 \\
\hline & Kanan depan & 306 & 292 & 283 & 881 & 239,67 \\
\hline \multirow[t]{5}{*}{2} & Kanan belakang & 358 & 362 & 329 & 1049 & 349,67 \\
\hline & Kiri depan & 320 & 310 & 230 & 860 & 286,67 \\
\hline & Kiri belakang & 175 & 217 & 144 & 536 & 178,67 \\
\hline & Total & & & & & 277,17 \\
\hline & Kanan depan & 107 & 185 & 101 & 393 & 131,00 \\
\hline \multirow[t]{5}{*}{3} & Kanan belakang & 62 & 107 & 87 & 256 & 85,33 \\
\hline & Kiri depan & 104 & 167 & 141 & 412 & 137,33 \\
\hline & Kiri belakang & 146 & 148 & 111 & 405 & 135,00 \\
\hline & Total & & & & & 122,16 \\
\hline & Kanan depan & 186 & 333 & 303 & 823 & 274,33 \\
\hline \multirow[t]{4}{*}{4} & Kanan belakang & 137 & 180 & 158 & 475 & 158,33 \\
\hline & Kiri depan & 336 & 215 & 180 & 731 & 243,67 \\
\hline & Kiri belakang & 367 & 363 & 296 & 1026 & 342,00 \\
\hline & Total & & & & & 254,58 \\
\hline
\end{tabular}

Hasil analisis menunjukkan bahwa susu sapi perah yang ada di Novisiat Claretian Benlutu dapat dikategorikan dalam mastitis subklinis. Hal ini terlihat pada uji $C M T$ dan dilanjutkan uji mikrobiologis susu dengan melihat jumlah bakteri yang ada dalam susu. Rata-rata jumlah bakteri pada sapi nomor $01,02,03,04<1 \times 10^{6}$ karena standarisasi kualitas susu menurut BPOM RI (2008) tentang cemaran mikroba maksimal $1 \times 10^{6} \mathrm{CFU} / \mathrm{mL}$.

Proses pencemaran mikroba pada susu dimulai ketika susu diperah karena adanya mikroba yang tumbuh di sekitar ambing, sehingga saat pemerahan bakteri tersebut terbawa dengan susu. Rombaut (2005) menyatakan bahwa tingkat kontaminasi berasal dari setiap sumber dan bergantung dari metode sanitasi yang dilakukan. Sumber kontaminasi yang sangat signifikan adalah dari permukaan yang kontak langsung dengan susu.

\subsection{Waktu Reduktase}

Pemanasan susu adalah upaya memperpanjang masa simpan pangan dengan menggunakan panas untuk membunuh semua mikroorganisme pathogen dan mengurangi mikroorganisme perusak yang terdapat dalam susu (Gaman dan Sherrington, 1994). Pemanasan susu dapat menurunkan total bakteri yang memenuhi dan sudah mencapai standar untuk pemanasan dalam waterbath. BSN (2011) berpendapat bahwa batas maksimum cemaran mikroba dalam susu segar $1 \times 10^{6} \mathrm{koloni} / \mathrm{ml}$. Semakin lama periode pemanasan maka semakin besar pula penurunan total bakteri pada susu. Demikian karena banyak spesies yang beragam dan memiliki ketahanan panas yang berbeda. Fardiaz (1992) berpendapat bahwa pencemaran bakteri setelah pemanasan dapat terjadi karena adanya bakteri yang tahan panas atau terjadi kontaminasi bakteri setelah proses pemanasan, misalnya peralatan yang digunakan. Berdasarkan hasil uji reduktase pada sampel susu segar di peternakan sapi perah Novisiat Claretian Benlutu, menunjukkan hasil yang baik dan sesuai dengan yang ditetapkan oleh Standar Nasional Indonesia (SNI) yaitu diatas 5 jam. Menurut Van den Berg (1998), waktu reduktase diatas 5 jam menunjukkan susu dengan kualitas yang sangat baik. Hal ini membuktikan bahwa susu segar yang diperoleh di Biara Novisiat Claretian Benlutu dalam keadaan baik dan layak konsumsi.

Lama atau tidaknya waktu perubahan warna methylen blue yang ada di dalam susu dipengaruhi oleh banyak atau tidaknya jumlah bakteri di dalam susu (Sari et al., 2013). Perinsip dari uji waktu reduktase adalah dalam susu terdapa enzim reduktase yang dibentuk oleh kuman-kuman, maka enzim ini akan mereduksi zat biru metilen menjadi larutan tidak berwarna. Semakin tinggi jumlah kuman di dalam susu, semakin cepat terjadi perubahan warna (Suardana dan Swacita, 2004). Uji reduksi biru metilen dapat memberikan gambaran perkiraan jumlah kuman yang terdapat di dalam susu, kemudian diamati waktu yang dibutuhkan oleh kuman untuk melakukan aktivitas yang dapat menyebabkan perubahan warna dari zat warna biru metilen.

Reduksi biru metilen didasarkan pada kemampuan bakteri di dalam susu untuk tumbuh dan menggunakan oksigen terlarut, yang menyebabkan penurunan kekuatan oksidasi-reduksi dari campuran tersebut, akibatnya biru metilen yang ; ditambahkan menjadi putih. Hadiwiyoto (1994) berpendapat bahwa semakin besar volume biru metilen yang ditambahkan dalam campuran susu maka semakin panjang waktu yang dibutuhkan untuk mereduksi biru metilen. Semakin lama hilangnya warna biru, menunjukkan jumlah bakteri yang semakin sedikit, yang menunjukkan kualitas susu nya semakin baik.Waktu reduktase susu segar yang diperoleh dari peternakan Novisiat Claretian Benlutu dapat dilihat pada Tabel 4. 
Tabel 4. Hasil Uji Reduktase Pada Susu Segar

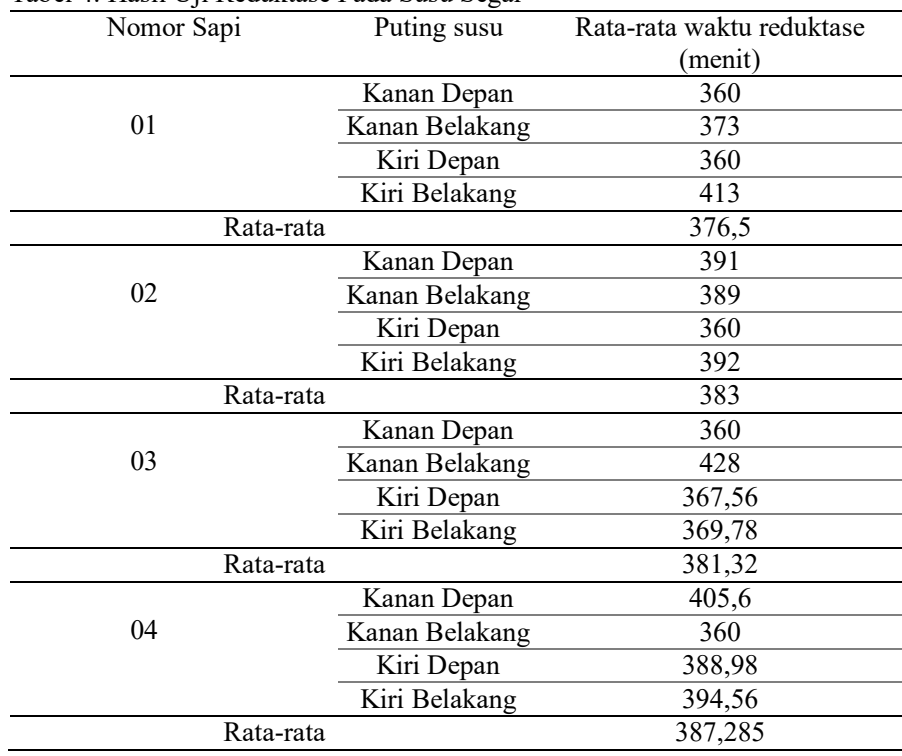

Berdasarkan hasil uji reduktase pada sampel susu segar di peternakan sapi perah Novisiat Claretian Benlutu, menunjukkan hasil yang baik dan sesuai dengan yang ditetapkan oleh Standar Nasional Indonesia (SNI) yaitu diatas 5 jam. Menurut Van den Berg (1998), waktu reduktase diatas 5 jam menunjukkan susu dengan kualitas yang sangat baik. Hal ini membuktikan bahwa susu segar yang diperoleh di Biara Novisiat Claretian Benlutu dalam keadaan baik dan layak konsumsi.

Lama atau tidaknya waktu perubahan warna methylen blue yang ada didalam susu dipengaruhi oleh banyak atau tidaknya jumlah bakteri di dalam susu (Sari et al., 2013). Prinsip dari uji waktu reduktase adalah dalam susu terdapat enzim reduktase yang dibentuk oleh kuman-kuman, maka enzim ini akan mereduksi zat biru metilen menjadi larutan tidak berwarna. Semakin tinggi jumlah kuman didalam susu, semakin cepat terjadi perubahan warna (Suardana dan Swacita, 2004). uji reduksi biru metilen dapat memberikan gambaran perkiraan jumlah kuman yang terdapat didalam susu, kemudian diamati waktu yang dibutuhkan oleh kuman untuk melakukan aktivitas yang dapat menyebabkan perubahan warna dari zat warna biru metilen.

Reduksi biru metilen didasarkan pada kemampuan bakteri didalam susu untuk tumbuh dan menggunakan oksigen terlarut, yang menyebabkan penurunan kekuatan oksidasi-reduksi dari campuran tersebut, akibatnya biru metilen yang ditambahkan menjadi putih. Hadiwiyoto (1994) berpendapat bahwa semakin besar volume biru metilen yang ditambahkan dalam campuran susu maka semakin panjang waktu yang dibutuhkan untuk mereduksi biru metilen. Semakin lama hilangnya warna biru, menunjukkan jumlah bakteri yang semakin sedikit, yang menunjukkan kualitas susunya semakin baik.

\section{Simpulan}

Induk sapi perah fase laktasi yang dipelihara di Biara Novisiat Claretian Benlutu mempunyai status mastitis subklinis, sehingga perlu pencegahan mastitis dalam tata laksana pemeliharaannya. Susu sapi perah yang dihasilkan dari peternakan tersebut dalam keadaan yang baik, dilihat dari jumlah bakteri dan lama waktu reduktase yang sudah sesuai dengan standar SNI.

\section{Pustaka}

Amran, M.U. 2013. Produksi dan Karakteristik Fisik Susu Sapi Perah Dengan Pemanfaatan Bahan Baku Lokal berupa Umbi Ubi Jalar (Ipomoea batalas) sebagai Pakan Alternatif. Jurusan Produksi Ternak. Fakultas Peternakan. Universitas Hasanuddin. Makassar.

Anri, A. 2008. Manual on Mastitis Control. The Project for Improvement of Countermeasures on the Productive Diseases on dairy Cattle in Indonesia. Jica Indonesia Office, Jakarta.

Ayano AA, Hiriko F, Simyalew AM, Yohannes A. 2013. Prevalence of subclinical mastitis in lactating cows in selected commercial dairy farms of Holeta district. Journal of Veterinary Medicine and Animal Health, 5 67-72.

Anderson, S., Dohoo, I., Olde Riekerink, R., Stryhn, H., 2010. Diagnosing intramammary infections: Evaluating expert opinions on the definition of 421 intramammary infection using conjoint analysis. Journal of Dairy Science, 93 : 2966- 2975

Badan Standardisasi Nasional [BSN]. 2011. SNI 3141.1:2011 Susu Segar Bagian I : Sapi.

Badan Pengawas Obat dan Makanan Republik Indonesia (BPOM RI). 2008. Uji Kualitas Susu Sapi Segar.

Fardiaz, S. 1992. Petunjuk Laboratorium Mikrobiologi Pengolahan Pangan.

Gaman, P. M. dan K. B. Sherrington. 1994. Ilmu Pangan: Pengantar Ilmu Pangan, Nutrisi dan Mikrobiologi. Edisi Kedua. Gadjah Mada University Press, Yogyakarta. Galton, D. M. 2004. Effect of an automatic postmilking teat dipping system on new intramammary infections and and iodine in milk. J. Dairy Sci, 87: 225- 231.

Hadiwiyoto, S. 1994. Teori dan Prosedur Pengujian Mutu Susu dan Hasil Olahnya. Edisi II. Penerbit Liberty, Yogyakarta.

Jayarao, B.M dan Wolfgang. 2003 Guidelines For Monitoring Bulk Tank Somatic Cell Counts. J. Dairy sci, 80:3561-3573.

Kirk, J.H. and Lauerman, L.H. 1994. Mycoplasma mastitis in dairy cows. Veterinarian. 16: 541-551.

Mellenberger, R. and Roth, C.J. 2000. California Mastitis Test (CMT), Fact Sheet. Department of Animal Sciences, Michigan State University and Department of Dairy Science, University of Wisconsin-Madison.

Poeloengan M. 2009. Aktivitas Air Perasan dan Ekstrak Etanol Daun Encok Terhadap Bakteri yang Diisolasi dari Sapi Mastitis Subklinis. Di dalam: Sani Y, penyunting. Seminar Nasional Teknologi Peternakan dan Veteriner 2009

Rahayu ID. 2009. Kerugian ekonomi mastitis subklinis pada sapi perah. Universitas Muhammadiyah Malang. [diakses 18 Maret 2019].

Rombaut R. 2005. Dairy Microbiology and Starter Cultures. Laboratory of Food Technology and Engineering. Gent University. Belgium.

Sari, M., I, Bagus N. S. Dan K. K. Agustina. 2013. Kualitas Susu Kambing Peranakan Etawa Post-Thawing Ditinjau Dari Waktu Reduktase Dan Angka Katalase. Indonesia Medicus Veterinus, 2 (2) : 202-207.

Suardana, IW. dan I. B. N. Swacita. 2004. Food Hygiene. Petunjuk Laboratorium. Fakultas Kedokteran Hewan. Universitas Udayana. Denpasar.

Soetarno T. 2003. Manajemen Budidaya Sapi Perah. Yogyakarta (ID) Universitas Gadjah Mada

Sudarwanto, M. 2009. Mastitis dan kerugian ekonomi yang disebabkannya. Makalah pada TOT JICA The 3rd. Oktober 2009, Cikole-Lembang, Bandung Barat.

Sudarwanto,M. and E.Sudarnika 2008. Hubungan antara pH Susu dengan Jumlah Sel Somatik Sebagai Parameter Mastitis Subklinik. Media Peternakan, 31(2): 107-113.

Sudarwanto, M., H. Latif \& M. Noordin. 2006. The relationship of the somatic cell counting to sub-clinical mastitis and to improve milk Quality. 1st International AAVS Scientific Conference. Jakarta, July 12-13, 2006

Sudhan, N. A. and N. Sharma. 2010. Mastitis- An Important Production Disease of Dairy Animals. SMVS‘ Dairy Year Book 2010. Jammu. pp. 72-88.

Sasongko, D.A., T. H. Suprayogi, dan S.M. Sayuthi. 2012. Pengaruh berbagai konsentrasi larutan kaporit $(\mathrm{CaHOCl})$ untuk dipping puting susu kambing perah terhadap total bakteri dan $\mathrm{pH}$ susu, J. Anim. Agric, 1 (2): 93-99.

Siregar AZ. 2010. Pengaruh celup puting sari buah mengkudu (Morinda Citrifolia. L) terhadap kasus mastitis subklinis pada sapi perah berdasarkan pemeriksaantotal plate count. Skripsi, Universitas Airlangga.

Suwito, W. dan S. Indarjulianto. 2013. Staphylococcus aureus penyebab mastitis pada kambing peranakan etawah: epidemiologi, sifat klinis, patogenesis, diagnosis dan pengendalian. Wartazoa, 23(1): 1-7.

Usmiati, S dan Abubakar. 2009. Teknologi Pengolahan Susu. Balai Besar Penelitian dan Pengembangan Pascapanen Pertanian. Bogor. $59 \mathrm{Hlm}$

Utami, K.B., L.E. Radiati dan P. Surjowardojo. 2014. Kajian kualitas susu sapi perah PFH (studi kasus pada anggota Koperasi Agro Niaga di Kecamatan Jabung Kabupaten Malang). Jurnal-Jurnal Ilmu Peternakan, 24(2): 58-66

Van den Berg., J.C.T. 1988. Dairy Technology in the Tropics and Subtropics PUDOC. Wageningen.

Winarno, F.G. 2004. Keamanan Pangan, Cetakan 1 Jilid 2. M-Brio Press, Bogor. 